Die Halogenatome sind in diesen Fällen also nicht in erster Linie Wirkungsträger, wie zuweilen vermutet wurde. Sie erfüllen vielmehr zweierlei Funktionen: Einerseits verursachen sie durch ihre Elektronenaffinität jene verringerte Ladungsdichte am Kohlenstoff, die wir als eigentliche Ursache der biologischen Aktivität ansehen. Andererseits erhöhen sie die Lipoidlöslichkeit der Verbindungen und schaffen dadurch eine Voraussetzung für das Vordringen der Verbindungen zum Wirkungsort, also zur lipoidhaltigen Nervensubstanz.

Wir werden auf die Beziehungen zwischen Konstitution und Wirkung zentral erregender und dämp- fender Verbindungen im pharmakologischen Zusammenhang noch ausführlicher zu sprechen kommen. Ferner werden wir später zeigen, daß das Prinzip des „biologisch aktiven Zentrums" in zahlreichen weiteren toxikologisch und pharmakologisch bedeutsamen Verbindungsklassen synthetischen und natürlichen Ursprungs regelmäßig zu finden ist. Auch Mitosegifte und cancerogene Stoffe lassen diese Merkmale erkennen, ebenso Verbindungen mit Wuchsstoffcharakter und solche mit anderer biologischer Aktivität, deren Eigenschaften ebenfalls mit einem Eingriff in fermentative Prozesse der Organismen in Zusammenhang stehen.

\title{
Structure of $\mathrm{Co}(\mathrm{CO})_{4} \mathrm{H}$ and $\mathrm{Fe}(\mathrm{CO})_{4} \mathrm{H}_{2}$
}

\author{
by Andrew D. Liehr \\ Bell Telephone Laboratories, Inc. Murray Hill, New Jersey \\ (Z. Naturforschg. 12 b, 95-96 [1957] ; eingegangen am 19. November 1956)
}

\begin{abstract}
By use of symmetry arguments new structures are proposed for the controversial metal-carbonyl hydrides of iron and cobalt. The proposed structures predict the possibility of a hindered rotation of the bonded hydrogen atoms.
\end{abstract}

The metal-carbonyl hydrides of iron and cobalt have puzzled chemists for a long time. Their physical properties have contradicted most of the previously proposed structures. They are known, by the electron diffraction work of Ewens and Lister ${ }^{1}$, to be pseudo-tetrahedral (that is, to have tetrahedrally arranged carbon monoxide ligands) and to behave as moderately strong acids ${ }^{2}$. Their infrared spectrum exhibits a metal-hydrogen stretch. ing mode ${ }^{3}$, but no carbon-hydrogen or oxygenhydrogen stretching modes ${ }^{3,4}$. And their nuclear magnetic resonance spectrum indicates a large diamagnetic shielding of the proton ${ }^{5}$. All of these experimental observations must be explained by any postulated configuration.

Assuming a tetrahedral arrangement of the carbon monoxide ligands, we propose that the hydro-

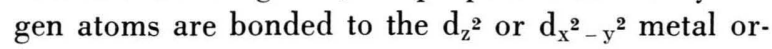

1 R. V. G. Ewens and M. W. Lister, Trans. Faraday Soc. 35, 681 [1939].

2 W. Hieber, Chemie 55, 25 [1942].

3 W. F. Edgell, C. Magee, and G. Gallop, J. Amer. chem. Soc. 78, 4185 [1956].

4 R. A. Friedel, I. Wender, S. L. Shufler, and H. W. SternBERG, J. Amer. chem. Soc. 77, 3951 [1955].

5 H. S. Gutowsky as quoted in Reference 4; F. A. Cotron and G. Wilkinson, Chem. and Ind. 44, 1305 [1956]. bitals in the case of cobalt and to both the $\mathrm{d}_{\mathrm{z}}{ }^{2}$ and

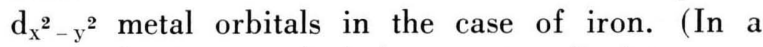
system having tetrahedral symmetry [point group $T_{d}$ ] the degenerate $d_{z}{ }^{2}$ and $d_{x}{ }^{2}-y^{2}$ orbitals of iron and cobalt [symmetry E] are nonbonding as far as the carbon monoxide ligands are concerned ${ }^{6}$; however, they are bonding for the attached hydrogen atoms.) This bonding scheme implies that the hydrogen atoms are located on the four-fold rotationreflection axes of the metal-carbon monoxide tetrahedron in the region between the metal atom and the carbon monoxide ligands (see Fig. $1 \mathrm{a}$ and $1 \mathrm{~b}$ ) The proposed electronic configuration (isoelectronic with $\left.\mathrm{Ni}(\mathrm{CO})_{4}\right)$ may be pictorially described as a "pseudo-nickel carbonyl" configuration ${ }^{2}$.

The bonding proposed in this note for $\mathrm{Co}(\mathrm{CO})_{4} \mathrm{H}$ and $\mathrm{Fe}(\mathrm{CO})_{4} \mathrm{H}_{2}$ is the same as that needed to explain the properties of $\left(\mathrm{C}_{5} \mathrm{H}_{5}\right)(\mathrm{Cr}, \mathrm{Mo}, \mathrm{W})$

6 The latter statement is rigorously true only if metal-carbonyl $\sigma$-bonding is assumed to predominate over metalcarbonyl $\pi$-bonding. See J. H. VAn Vleck, J. chem. Physics. 3, 803 [1935].

7 A. D. Liehr, Naturwissenschaften, in press.

8 E. O. Fischer, W. Hafner, and H. O. Stahl- Z. anorg. u. allg. Chem. 282, 47 [1955].

- T. S. Piper and G. Wilkinson, J. Inorg. Nuc. Chem. 3, 104 [1956]. 


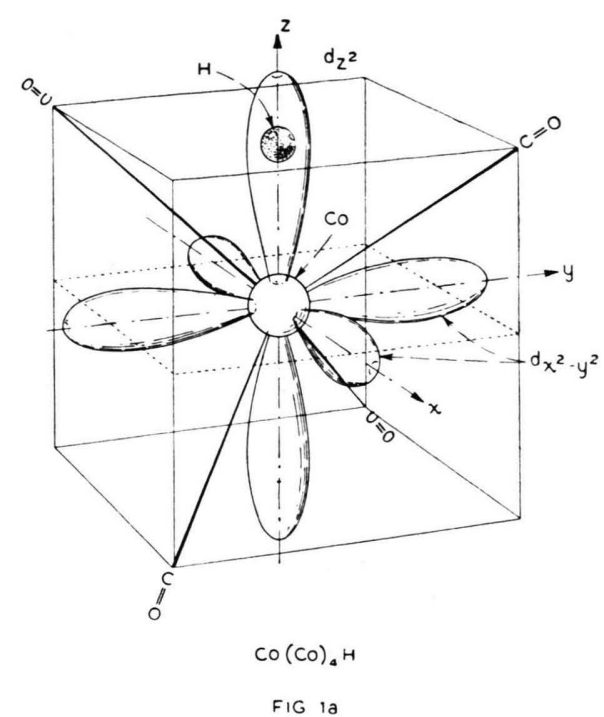

(CO) ${ }_{3} \mathrm{H}^{7,8,9}$. And, as for these latter compounds, we expect the hydrogen to be weakly acidic because of the greater electron affinity of the metal nucleus as compared with that of the proton ${ }^{2}$. Since the hydrogen is located near the centroid of maximum charge density of the metal-carbon bond, we also expect the proton to exhibit the large diamagnetic shielding observed in high resolution-NMR measurements ${ }^{5,9}$. And because of the relatively loose bonding of the hydrogen, we expect to find the metal-hydrogen stretching mode in the low energy region of the infrared ${ }^{3}$.

These configurations have several advantages over previously proposed structures 1,10 . The structure of Ewens and Lister, with a $\mathrm{C}-\mathrm{OH}$ bond, is untenable because it fails to explain the absence of $\mathrm{O}-\mathrm{H}$ stretching frequencies and the anomalous diamagnetic shielding of the proton. The proposed structure

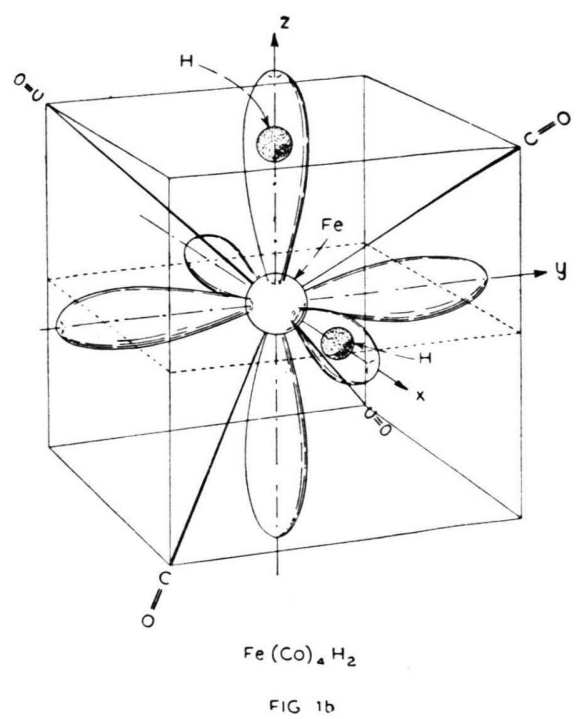

for $\mathrm{Co}(\mathrm{CO})_{4} \mathrm{H}$ of Edgell and Gallup, though explaining its physical properties, is not appealing chemically. The great stability of the carbon-oxygen $\pi$-bonds would, on chemical grounds, seem to preclude their disruption by hydrogenation. Thus one would expect the structure of EDGell and Gallup to yield a chemically unstable species.

It should be noted that the structures given here (see Fig. 1) indicate that the bonded hydrogen atom is capable of undergoing hindered rotation in a field of tetrahedral symmetry, the maxima lying in the direction of the metal-carbon bonds (that is, on the three-fold axes) and the minima on the $\pm x, \pm y$, $\pm z$ axes (that is, on the four-fold rotation reflection axes).

10 W. F. Edgell and G. Gallup, J. Amer. chem. Soc. 77, 5762 [1955]; 78, 4188 [1956]. 